\title{
ANALISIS KUALITASPELAYANAN PASIEN KLINIK PRATAMA DENGAN METODE SERVQUAL DAN IMPORTANCE PERFORMANCE ANALYSIS
}

\author{
R. Faris Mukmin Kalijogo*, Wiwiek Rabiatul Adawiyah, Ratno Purnomo \\ Fakultas Ekonomi dan Bisnis, Universitas Jenderal Soedirman, Indonesia \\ *farismukmink@gmail.com
}

\begin{abstract}
Abstrak
Kepuasan pelanggan mampu menggambarkan suatu kesesuaian harapan dan kenyataan suatu kualitas layanan. Desain strategi peningkatan kualitas pelayanan kesehatan yang berorientasi pada kepuasan pasien mampu memberikan keunggulan dalam persaingan yang ketat. Identifikasi kebutuhan pasien sebagai pelanggan menggunakan integrasi metode Service Quality dan Importance Performance Analysis memudahkan manajemen untuk mengetahui kebutuhan pasien sebagai dasar pengembangan kualitas pelayanan. Penelitian studi kasus dengan pendekatan kualitatif ini bertujuan untuk mengupayakan peningkatan kualitas mutu layanan klinik pratama dengan analisis Service Quality dan Importance Performance Analysis. Data diperoleh dari pembagian kuesioner pada 100 orang pasien klinik pratama AP sebagai responden menggunakan teknik convenience sampling berdasarkan kriteria inklusi dan eksklusi. Penelitian ini memperoleh sejumlah 25 atribut kebutuhan pelanggan. Data pelanggan diklasifikasikan menjadi 4 atribut pada aspek keandalan (reliability), 4 atribut pada aspek responsiveness, 4 atribut keyakinan (assurance), dan 4 atribut pada dimensi empati (empathy). Secara keseluruhan menggunakan metode Service Quality atribut memiliki nilai Gap Score ratarata -0.39 poin. Hasil prioritas atribut dengan analisisImportance Performance Analysisantara lain :atribut ketepatan jadwal pelayanan $(-1.06)$, pelayanan sopan dan ramah $(-0.93)$, dan ketersediaan penunjang medis dan apotik $(-0.69)$. Prioritas ini akan menjadi masukan bagi klinik sebagai pertimbangan untuk meningkatkan kualitas pelayanan.
\end{abstract}

Kata Kunci: Kualitas pelayanan, Servqual, IPA

\begin{abstract}
Customer satisfaction is able to describe a suitability of expectations and perception of a service quality..The strategic design to improve the quality of health services oriented to patient satisfaction. Identifying patient needs as customers using integration methods of Service Quality and Importance Performance Analysis provides management to understand patient needs as a basis for developing service quality. This research is a case study with qualitative analysis to improve the services quality of pratama clinic using Service Quality and the Importance Performance Analysis method. Data obtained from the distribution of questionnaires to 100 pratama AP clinical patients as respondents used convenience sampling techniques based on inclusion and exclusion criteria. This study received a number of 25 attributes of customer needs. Customer data expects to be 4 attributes on the aspect of approval, 4 attributes on aspects of responsiveness, 4 attributes of assurance, and 4 attributes on the dimensions of empathy. Service quality analyze that all of attributes have gap score average -0.39 points. Results of priority attributes with analysis Importance of Performance Analysis include: attributes of service schedule accuracy (-1.06), polite and friendly service (-0.93), and medical support and pharmacies $(-0.69)$. This priority will be input to the clinic as a consideration to improve service quality.
\end{abstract}

Keywords: Service Quality, Servqual, IPA 


\section{PENDAHULUAN}

Pelayanan adalah proses pemenuhan kebutuhan konsumen oleh pemberi pelayanan menggunakan prosedur, sistem dan metode tertentu (Moenir, 2010). Pelayanan di bidang kesehatan terwujud antara pasien sebagai pelanggan dan fasilitas kesehatan. Menurut Pratiwi (2014), kepuasan merupakan kesesuaian hasil penilaian konsumen terhadap berbagai aspek pelayanan yang dirasakan dan diharapkan, sehingga kepuasan pasien dapat menjadi evaluasi pihak pemberi layanan terkait kualitas pelayanannya.UUD 1945 pasal $28 \mathrm{~h}$ ayat 1 mengamanatkan pelayanan kesehatan sebagai hak dasar bagi seluruh warga negara Indonesia. Indonesia mendukung Universal Health Coverage (UHC) dalam peraturan pelaksanaan Sistem Jaminan Sosial Nasional (SJSN) dan diselenggarakan oleh Badan Penyelenggara Jaminan Sosial (BPJS) dan tertuang dalam UU No.40 Tahun 2004. UU No. 40 tahun 2004 memastikan setiap warga negara memiliki akses yang adil terhadap pelayanan kesehatan yang bermutu dan terjangkau(Kemenkes RI, 2010).

Fasilitas kesehatan tingkat pertama (FKTP) dalam era BPJS menjadi ujung tombak pelayanan kesehatan dan menjadi pusat keanggotaan BPJS. Menurut Wijono dalam Safrudin (2012) pelayanan kesehatan yang bermutu berorientasi pada kepuasan pasien mampu bertahan di tengah persaingan global yang semakin kuat. Data BPJS Banyumas (2018), Wilayah Banyumas terdapat 33 buah klinik pratama, 39 buah puskesmas dan 43 dokter praktik perorangan. Data Badan Pusat Statistik (2017) sejumlah 196.662.064 jiwa atau sekitar 75,09 \% yang terdaftar sebagai anggota BPJS dari total warga negara Indonesia. Data BPJS (2018) menyebutkan penduduk Kabupaten Banyumas baru mencapai 74,98\% dari total penduduk sebesar 1.635.909 jiwa yang terdaftar sebagai anggota BPJS.

Data internal Klinik Amanda Pratama mencatatkan klinik pratama ini telah memiliki keanggotaan BPJS pada Februari 2018 sejumlah 10.147 orang dan memiliki kapasitas hingga sejumlah 23.000 orang anggota. Klinik ini ditunjang dengan 5 orang dokter umum dan 1 orang dokter gigi serta 5 orang tenaga paramedis yang siap melayani secara optimal. Kepuasan pasien sebagai peserta asuransi BPJS merupakan salah satu faktor acuan dalam menentukan keberhasilan progam pelayanan. Kualitas yang baik dari suatu layanan bukan berdasar pada persepsi penyedia jasa, namun berdasarkan pada persepsi konsumen, karena konsumenlah yang menikmati pelayanan yang diberikan oleh FKTP (Trisnawati, 2015). Data internal klinik menunjukkan terjadinya peningkatan komplain pasien pada bulan Januari 2018 sejumlah 5 laporan dan terus meningkat hingga 11 laporan di bulan Maret dan mencapai 21 laporan pada bulan Juni 2018. Data laporan komplain pelanggan selama 6 bulan dari pelanggan diperoleh laporan berupa permasalahan tentang lama waktu layanan, pelayanan dokter dan paramedis, dan fasilitas klinik. Data ini mengindikasikan terdapat ketidaksesuaian antara keinginan dan harapan pelanggan terkait kualitas pelayanan di Klinik Amanda Pratama yang belum digali oleh klinik dan berpeluang menjadi permasalahan di masa yang akan dating sehingga perlu dilakukan evaluasi sebagai upaya peningkatan kualitas layanan klinik.

Penelitian sebelumnya yang membahas kualitas layanan FKTP di wilayah Banyumas, Penelitian Kurniawan (2012), Sartinah (2008), Suganda (2010), dan Nuresa (2010) menunjukkan bahwa kurang dari 60\% pasien yang menyatakan kualitas layanan kesehatan pada FKTP di Banyumas yang mencapai indikator kurang memuaskan. Berdasarkan beberapa hal tersebut, peneliti ingin meneliti kepuasan pelayanan pasien BPJS pada klinik pratama di wilayah Banyumas, dan sangat jarang dijumpai penelitian senada pada era BPJS di wilayah Kabupaten Banyumas. Penelitian ini akan difokuskan pada analisis faktor kepuasan pelanggan dan menentukan prioritas faktor kepuasan pelanggan menggunakan analisis Servqual dan Importance Perfomance Analysis (IPA).

Metode ini telah diaplikasikan pada jasa pelayanan kesehatan beberapa penelitian di Indonesia, seperti pada penelitian Wahyuni (2014), Magdalena et al. (2013) dan Iswandari (2011), berdasarkan fokus penelitian kebanyakan analisis cakupan dalam skala rumah sakit maupun FKTP puskesmas dan hanya sedikit literatur dalam cakupan skala klinik pratama. Penelitian terdahulu telah menunjukkan kesesuaian dan manfaat pada penyelasaian masalah 
kualitas layanan pada berbagai tingkatan pelayanan jasa kesehatan. Magdalena et al. (2013) konsumen pelayanan kesehatan akan membandingkan pelayanan kesehatan yang diterima dengan harapan terhadap pelayanan yang diberikan sehingga membentuk tingkat kepuasan. Tingkat kepuasan pasien menunjukkan tingkat keberhasilan suatu layanan kesehatan dalam meningkatkan mutu pelayanannya. Pengukuran tingkat kepuasan pasien dapat dilakukan dengan menggunakan berbagai metode pengukuran. Dari beberapa metode yang ada, berbagai riset menunjukkan bahwa instrumen Service Quality (Servqual) valid untuk berbagai konteks layanan (Iswandari, 2011). Metode Servqual mempunyai kelebihan yaitu dapat mengetahui tingkat kepuasan pelanggan pada setiap atribut pelayanan, namun metode ini memiliki kekurangan yaitu penilaiannya secara subyektif dan perbaikan kualitas layanan hanya berdasarkan pada gap yang memiliki nilai tertinggi saja.Rahayu (2016) metode Importance Performance Analysis (IPA) memiliki kelebihan memetakan persepsi pelanggan terhadap tingkat kepentingan (importance) aspek pelayanan dalam persepsi pelanggan terhadap kinerja (performance) aspek pelayanan yang bertujuan mengidentifikasi aspek yang perlu ditingkatkan untuk menjaga kepuasan pelanggan, dengan hasil dan skala yang mudah dimengerti dan berbiaya rendah.Integrasi kedua metode ini akan saling melengkapi guna memperoleh hasil analisis yang baik dan tepat. Perpaduan metode ini sesuai dengan tujuan pada penelitian ini yaitu menganalisis kepuasan pasien dan mengetahui prioritas perbaikan yang harus dilakukan oleh klinik dalam upaya peningkatan mutu pelayanan kesehatan.

\section{TINJAUAN PUSTAKA}

\section{Konsep Kepuasan Pelanggan}

Kepuasan pelanggan telah menjadi konsep sentral dalam teori dan praktek pemasaran, serta merupakan faktor yang esensial bagi kegiatan bisnis. Dalam buku teks standar Marketing Management yang ditulis Kotler (2009) dan banyak dijadikan acuan, menegaskan bahwa kepuasan pelanggan adalah tingkat perasaan seseorang setelah membandingkan kinerja yang ia rasakan dibandingkan dengan harapannya dan dapat dirumuskan sebagai evaluasi pascabeli. Apabila persepsi terhadap kinerja tidak bisa memenuhi harapan, maka akan terjadi ketidakpuasan.

Craig-Less dalam Tjiptono(2006) menyatakan bahwa pemahaman perilaku konsumen mengenai ketidakpuasan jauh lebih mendalam daripada dalam kepuasan pelanggan. Pemahaman ini berasal dari dua bidang penelitian utama, yaitu riset disonansi dan perilaku komplain. Menurut Tjiptono (2006) disonansi purnabeli berbeda dengan ketidakpuasan. Disonansi purnabeli konsumen berhubungan dengan keraguandalam memilih dan mengambil keputusan dalam pembelian. Konsumen bimbang dalam situasi ini mengenai ketepatan pembelian produk yang dilakukannya danfaktor kecemasan juga menjadi pencetus terjadinya disonansi. Sedangkan situasi ketidakpuasan terjadi setelah adanya pengalaman penggunaan produk atau jasa yang dibeli dan kinerja produk dirasakan tidak memenuhi harapannya.

\section{Service Quality (Servqual)}

Kualitas jasa dapat dianalisis dengan servqual yang menjadi model analisis di bidang manajemen dan pemasaran jasa. Servqual dikembangkan oleh Parasuraman (1988) mampu menjelaskan Customer-Perceived Quality dan 5 kesenjangan (gap) penyebab kegagalan sebuah pelayanan seperti pada gambar 1 . 


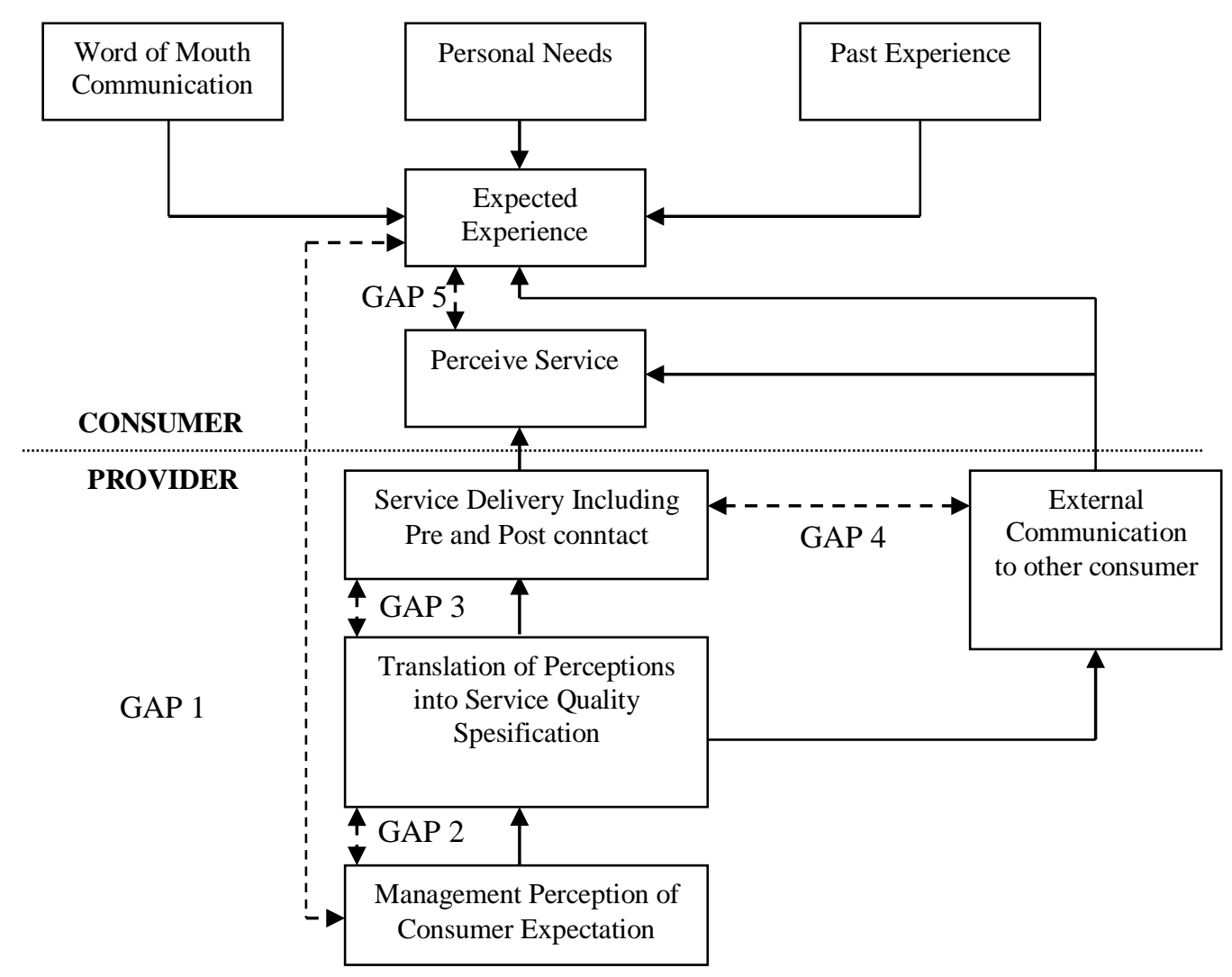

Gambar 1. Model Kesenjangan Servqual (Parasuraman, 1985)

Kesenjanganpertama yaitu ketidaksesuaian persepsi manajemen dan harapan pelanggan yang disebabkan oleh manajemen gagal memahami harapan pelanggan karena adanya kegagalan komunikasi vertikal yang, ketidaksiapan memberi perhatian kepada pelanggan, interaksi tidak langsung dengan pelanggan, orientasi riset pemasaran minimal, dan ketiadaan upaya identifikasi harapan pelanggan. Kesenjangankedua yaitu ketidaksesuaian persepsi manajemen dan spesifikasi mutu yang disebabkan oleh desain dan standar pelayanan yang tidak sesuai dengan persepsi harapan konsumen karena kesalahan perumusan tujuan organisasi, kegagalan mengidentifikasi secara akurat, dan komitmen mutu yang rendah menyebabkan kensenjangan ini. Kesenjangan ketiga adalah ketidaksesuaian spesifikasi mutu layanan dan penyampaian layanan yang disebabkan oleh permasalahan pemberian pelayanan yang tidak sesuai dengan standar oleh karyawan. Kesenjangankeempat yaitu ketidaksesuaian penyampaian pelayanan dan komunikasi eksternal yang disebabkan oleh manajemen tidak memberikan pelayanan sesuai yang telah dikomunikasikan. Kesenjangan terakhir adalah ketidaksesuaian pelayanan yang dirasakan dan diharapkan disebabkan oleh persepsi pelanggan yang salah terkait mutu pelayanan dan perbedaan cara mengukur kinerja.

Kualitas (Q) didefinisikan sebagai derajat dan arah ketidaksesuaian persepsi dan

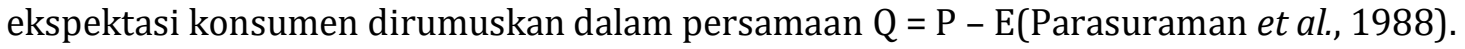

Persepsi (P) sebagai pengalaman yang dirasakan oleh pelanggan dan Ekspektasi (E) dirumuskan sebagai keinginan/harapan konsumen tehadap suatu layanan. Pelayanan berbasis harapan pelanggan dapat diperoleh organisasi dengan berusaha meminimalkan setiap kesenjangan. Berikut adalah beberapa langkah untuk meningkatkan mutu pelayanan oleh manajemen, antara lain Identifikasi faktor mutu pelayanan, Hal ini diperoleh dengan penelitian pada pelanggan, pesaing, dan manajemen terkait faktor tersebut, pengelolaan hasil ekspektasi pelanggan dan perusahaan mengkomunikasikan pada pelanggan, pengelolaan faktor mutu pelayanan yang menentukan hubungan pelanggan dan manajemen, dan Pengembangan budaya 
mutu berkenaan dengan nilai suatu manajemen yang perwujudannya didukung oleh seluruh bagian manajemen (Tjiptono 2003).

Analisis servqual yang terdiri dari lima dimensi kualitas jasa yaitu bukti fisik, kehandalan, ketanggapan, jaminan dan kepastian, dan perhatian yang tulus. Bukti fisik (tangibles) berupa penampilan dan kemampuan sarana dan prasarana fisik perusahaan dan keadaan lingkungan sekitarnya adalah bukti nyata dari pelayanan yang diberikan oleh pemberi layanan jasa yang meliputi fasilitas fisik (gedung), teknologi (peralatan dan perlengkapanyang digunakan), penampilan pegawai serta sarana komunikasi.Kehandalan (reliability) merupakan emampuan perusahaan untuk memberikan pelayanan sesuai yang dijanjikan secara akurat dan terpercaya. Hal ini harus sesuai dengan harapan konsumen seperti kinerja yang tepat waktu, pelayanan tanpa kesalahan, sikap simpatik dan terpercaya.Ketanggapan (responsiveness) adalah suatu kemauan untuk membantu dan memberikan pelayanan yang cepat dan tepat kepada konsumen dengan penyampaian informasi yang jelas. Jaminan dan kepastian (assurance) merupakan pengetahuan, kesopan-santunan dan kemampuan para pegawai perusahaan untuk menumbuhkan rasa percaya konsumen kepada perusahaan.

\section{Importance Performance Analysis (IPA)}

Importance-Performance Analysis dikemukakan oleh Imartilla \&James dalam Tjiptono(2005) dalam artikel berjudul Importance-Performance Analysis yang dipublikasikan di Journal of Marketingdigunakan untuk mengidentifikasi target pasar dan atribut pelayanan, berdasar pada tingkat kepentingan dan dampaknya bagi performance perusahaan secara keseluruhan. Manajemen memperoleh gambaran berdasarkan4 kuadaran diagram kartesius terkait atribut yang dikehendaki dan memberikan perbaikan dan dapat dibandingkan dengan atribut yang berlebihan dalam penggunaan sumber daya dan memberi keuntungan minimal bagi kepuasan konsumen. IPA hanya memiliki 2 dimensi, X dan Y. Kepuasan konsumen (performance)digambarkan dalam sumbu $\mathrm{X}$, sedangkan sumbur $\mathrm{Y}$ menggambarkan tingkat kepentingan (importance). Matriks ini bermanfaat sebagai pedoman untuk mengalokasikan sumber daya terbatas pada bidang yang spesifik, sehingga perbaikan kinerja dapat berdampak besar pada kepuasan pelanggan. Matriks ini juga menunjukkan bidang atau atribut tertentu yang perlu dipertahankan dan aspek-aspek yang perlu dikurangi prioritasnya.

Penentuan strategi dilakukan berdasarkan letak atribut dalam keempat kuadran. Kuadran 1 (Concentrate Here), yaitu wilayah yang berisi atribut yang dianggap penting oleh responden namun atribut ini belum sesuai harapan sehingga tingkat kepuasannyarendah dan harus ditingkatkan. Organisasi harus melakukan perbaikan secara terus-menerus sehingga performanceatributkuadran ini akan meningkatkan. Kuadran 2 (Keep Up The Good Work), yaitu wilayah berisiatribut yang dianggap penting oleh responden dan sudah sesuai dengan yang diharapkan sehingga tingkat kepuasannya relatif lebih tinggi. Atribut dalam kuadran ini harus dipertahankan karena seluruh atributmembuat pelayanan bernilai lebih bagi responden. Kuadran 3 (Low Priority), yaitu wilayah dengan atribut yang dianggap kurang penting dan kinerjanya tidak terlalu istimewa. Peningkatan atribut dalam kuadran ini dapat kurang diprioritaskan karena pengaruhnya kecil terhadap manfaat dan kepuasan responden. Kuadran 4 (Possible Overskill), yaitu wilayah berisi atribut yang dianggap kurang penting oleh responden tetapi dirasakan sudah cukup memuaskan dan atribut dalam kuadran ini harus dipertahankan.

\section{METODE PENELITIAN}

Penelitian ini berupa studi kasus kualitatifanalisis kualitas pelayanan Klinik Pratama APdi Kabupaten Banyumas. Penelitian ini menganalisis kualitas pelayanandan menentukan prioritas kepuasan pelanggan. Penelitian ini dilakukan di Klinik Pratama AP Banyumas yang merupakan salah satu fasilitias kesehatan tingkat pertama yang bekerjasama dengan pihak BPJS di wilayah Kabupaten Banyumas.Populasi penelitian ini adalah seluruh pasien BPJSrawat jalan Klinik Pratama AP pada bulan Agustus-November tahun 2018. Teknik sampling menggunakan metode non probability sampling berupa convenience sampling, yaitu pemilihan sampel tanpa sistem acak pada populasi tertentu yang tersedia dan dapat ditemui oleh peneliti saat penelitian dilakukan (Sugiyono,2012). Jumlah sampel dalam penelitian menggunakan rumus Slovin dengan ukuran 
populasi sampel sejumlah 10.147 orang dan persen kelonggaran sebesar $10 \%$ makan diperoleh responden sebesar 99,02 dan dibulatkan menjadi 100 orang (Notoatmodjo, 2010). Penelitian ini menggunakan kriteria inklusi dan eksklusi untk menentukan kelayakan responden yang sesuai dengan penelitian. Kriteria Inklusi penelitian ini adalah:Pasien yang sedang berkunjung ke Klinik Pratama Amanda, Pasien berusia $\geq 17$ tahun atau sudah menikah yang saat mendapatkan pelayanan dalam kondisi sadar dan masih bisa menilai lingkungannya, Responden yang telah berkunjung dan memperoleh pelayanan kesehatan lebih dari 1 kali, Responden merupakan pasien dengan keanggotaan BPJS yang terdaftar di klinik dan Pasien yang bersedia menjadi responden dan mengisi lembar persetujuan menjadi responden penelitian. Kriteria eksklusi pasien sebagai responden unutk penelitian ini antara lain:Pasien yang belum mencapai usia 17 tahun atau belum menikah, Pasien yang belum mencapai kunjungan lebih dari satu 1 kali, Pasien bukan merupakan keanggotaan BPJS dan tidak terdaftar di klinik, Pasien tidak dapat memahami kuesioner atau kesulitan karena kondisi kesehatan yang tidak memungkinkan menjadi responde, dan Pasien tidak bersedia menjadi responden.

Pengumpulan data dilakukan dengan pengisian kuesioner. Kuesioner adalah daftar pertanyaan logis yang berhubungan dengan permasalahan yang diteliti dan memiliki jawaban yang bermakna (Sugiyono, 2012). Kuesioner tersusun atas 25 item penilaian yang terklasifikasi dalam lima dimensi kualitas pelayanan jasa dari Parasuraman et al. (1985), yaitu, bukti langsung (tangible), kehandalan (reliability), daya tangkap (responsiveness), jaminan (assurance), dan empati (emphaty). Kuesioner yang diajukan berisi pernyataan tentang persepsi atau kinerja dan harapan pasien. Pernyataan persepsi untuk menilai tentang bagaimana pelayanan yang dirasakan di Klinik, sedangkan pernyataan harapan yaitu pernyataan yang dibuat untuk mengetahui harapan pasien terhadap pelayanan yang diinginkan. Skala Likert 1 - 5 digunakan dalam penilaian kuesioner. Interpretasi skala digunakan untuk menerjemahkan skala pada bagian harapan dan kenyataan. Bagian harapan skala 1 bermakna tidak diharapkan (TH), skala 2 kurang diharapkan $(\mathrm{KH})$, skala 3 cukup diharapkan $(\mathrm{CH})$, skala 4 diharapkan $(\mathrm{H})$ dan skala 5 sangat diharapkan (SH). Bagian kenyataan interpretasi skala 1 adalah tidak sesuai harapan (TSH), skala 2 kurang sesuai harapan (KSH), skal 3 cukup sesuai harapan (CSH), skala 4 sesuai harapan (SH) dan skala 5 sangat sesuai harapan (SSH). Uji instrumen dengan menggunakan uji validitas dan reliabilitas.Analisis dilakukan dengan Software SPSS 16 for windows. Uji validitas diperoleh dengan analisis korelasi pearson dan apabila nilai $r$ hitung $>$ dari nilai $r$ tabel maka dinyatakan valid (Sugiyono, 2012).Uji Reliabilitasdilakukan dengan uji statistik Cronbach Alphadan dinyatakan reliabel jika memberikan nilai Cronbach Alpha > 0,60 (Sugiyono, 2012). Teknik analisis data berupa analisis servqual dan importance performance analysis (IPA).

\section{HASIL DAN PEMBAHASAN}

\section{Hasil Uji Validitas}

Uji validitas menggunakan teknik korelasi Pearsonmenggunakan SPSS 16. Uji Validitas bernilai valid bila $r$ hitung positif dan nilainya lebih besar atau sama dengan nilai $r$ tabel $5 \%$ (Sugiyono, 2012). Pada tabel 5\% nilai $r$ tabel satu sisi sejumlah 30 orang responden sebesar 0.361 , jadi bila nilai $r$ hitung $>0.361$ maka butir instrumen itu dinyatakan valid. Penelitian ini menunjukkan hasil pengujian validitas menyatakan semua butir pertanyaan adalah valid.

\section{Hasil Uji Reliabilitas}

Uji reliabilitas bertujuan menilai tingkat konsistensi instrumen dalam memberikan hasil yang sama dalam waktu, responden dan pengujian yang berbeda (Sugiyono, 2012). Instrumen penelitian ini adalah kuesioner yang menggunakan skala interval dan menggunakan teknik uji cronbach alpha (Uma, 2006). Kriteria pengujian berdasarkan cronbach alpha bernilai hitung $>0,60$ maka instrumen yang diuji tersebut dapat dinyatakan telah reliabel. Pada penelitian ini kuesioner memiliki hasil $r$ yang reliabel dengan nilai $r$ kuesioner kenyataan sebesar 0,759 dan 0,970 untuk kuesioner harapan. 


\section{Deskripsi Responden}

Responden pada penelitian ini adalah seluruh pasien yang keanggotaan BPJSnya berada di klinik pratama ini. Hasil penyebaran kuesioner kepada seluruh responden, peneliti memperoleh data terkait identitas responden yang menjadi objek penelitian, berikut adalah hasil pengolahan data identitas responden yang dapat menjadi informasi karakteristik responden penelitian ini.

Tabel 4.3 menunjukkan responden penelitian ini sejumlah 100 orang terbagi dalam 4 kelompok usia, kelompok usia terbanyak pada rentang 46-60 tahun sejumlah 39\%, pada urutan kedua adalah rentang usia 31-45 tahun sebesar 30\% dan rentang usia lebih dari 60 tahun merupakan rentang usia dengan jumlah paling sedikit sebesar $12 \%$. Data ini sesuai dengan penelitian Umar (2001) yang menyatakan pertambahan usia akan diikuti dengan penurunan kemampuan fisiologis manusia yang biasanya dimulai pada rentang usia 30-45 tahun.

Klinik pratama perlu mempertimbangkan hal ini sebagai sebuah faktor yang menentukan desain pelayanan yang sesuai dengan rentang usia tersebut. Gunarsa (2008) mengungkapkan bahwa bertambahnya umur seseorang dapat berpengaruh pada kesehatannya, dimana terjadi kemunduran struktur dan fungsi organ, sehingga masyarakat yang berusia lebih tua cenderung lebih banyak memanfaatkan pelayanan kesehatan dibandingkan dengan usia muda.Pasien dengan usia tua dan penyakit kronik lebih cepat menerima keadaan keterbatasan fisik dari pada orang yang lebih muda. Hal ini karena orang usia tua umumnya lebih bersifat terbuka, sehingga pasien usia tua tuntutan dan harapannya lebih rendah dari pasien usia muda.

Responden penelitian ini didominasi oleh responden berjenis kelamin perempuan sebesar 59\% dan $41 \%$ untuk responden laki-laki. Jenis kelamin memiliki pengaruh pada pandangan terhadap jasa yang diberikan. Perempuan lebih banyak melihat penampilan secara detail, sementara laki-laki tidak mengindahkan hal tersebut. Cara mengelola hubungan untuk kaum laki-laki, mereka cenderung lebih cuek dengan hal yang dikemukakan oleh perempuan, karena itu mereka dianggap lebih fleksibel dibandingkan perempuan (Gunarsa, 2008).

Terdapat lima kelompok pekerjaan yang menggambarkan karakteristik responden penelitian ini antara lain, kelompok wiraswasta sebesar $29 \%$ yang mendominasi dari keseluruhan kelompok, PNS/TNI/POLRI sejumlah 24\% pada urutan kedua dan sejumlah 19\% merupakan kelompok pelajar dan mahasiswa. Kelompok responden yang tidak bekerja hanya sebesar $10 \%$ dari keseluruhan responden. Data ini menggambarkan mayoritas pasien yang menjadi responden wirasawata dan pekerjaan yang bekerja di pemerintah. Sebagian besar data ini senada dengan penelitian Arief (2015) yang menunjukkan sebagian besar profesi anggota BPJS adalah wiraswasta dan pegawai negeri yang memiliki tingkat kesadaran terhadap jaminan kesehatannya, pekerjaan tersebut dinilai memiliki kemampuan ekonomi yang lebih baik di kelas masyarakat yang lain.

Mayoritas responden berpendidikan S1 sebesar 41\% dan 26\% berpendidikan SMA yang mendominasi kelompok karakteristik pendidikan. Terdapat enam kelompok karakteristik pendidikan dalam responden penelitian ini, kelompok pendidikan tamatan SD merupakan kelompok dengan jumlah terendah yaitu sebesar $2 \%$. Hasil penelitian yang diakukan oleh Budiman (2010) pendidikan memiliki hubungan dengan kepuasan pasien $(p=0,008)$. Hasil ini jelas menyatakan bahwa orang yang berpedidikan tinggi akan memiliki kriteria dan standar pelayanan yang lebih tinggi sesuai dengan referensi pelayanan yang dimilikinya sehingga akan merasa mudah tidak puas dibandingkan dengan orang yang berpendidikan rendah. Pendidikan tinggi menentukan kelas sosial di masyarakat, mayoritas masyarakat dengan pendidikan tinggi akan lebih kritis dibandingkan pendidikan yang rendah, hal ini akan berdampak pada tingkat harapan seorang pasien terhadap kualitas pelayanan kesehatan yang diharapkannya.

Frekuensi kunjungan responden di Klinik Pratama BPJS sebagai kunjungan sehat atau kunjungan sakit di kelompokkan menjadi 3 kelompok frekuansi kunjungan, 2 kali, 3-5 kali dan lebih dari 5 kali kunjungan ke klinik pratama. Sebagian besar responden penelitian ini mengatakan cukup sering datang ke klinik pratama, sejumlah $52 \%$ telah berkunjung lebih dari 5 kali dan 45\% telah berkunjung 2-5 kali sedangkan hanya 3\% yang berkunjung 2 kali. Semakin tinggi frekuensi kunjungan pasien di klinik pratama, pasien akan semakin paham akan kelebihan dan kekurangan sebuah pelayanan secara detail sehingga tingkat kunjungan semakin tinggi pasien semakin mampu mendeskripsikan sebuah pelayanan secara baik (Azwar, 2000). 


\section{Hasil Analisis metode Servqual}

Metode Servqual mengidentifikasi kesenjangan nilai harapan dan kenyataan yang dirasakan pasien terhadap suatu atribut kebutuhan. Penilaian ini diwujudkan dalam skala likert 1-5 untuk setiap atribut harapan dan kenyataan (Parasuraman, 1988). Pada bagian harapan skala 1 bernilai tidak diharapkan (TH), 2 bernilai kurang diharapkan (KH), 3 bernilai cukup diharapkan (CH), 4 bernilai Diharapkan (H), dan 5 bernilai sangat diharapkan (SDH). Sedangkan untuk bagian kenyataan, skala 1 bernilaitidak sesuai harapan (TSH), 2 bernilai kurang sesuai harapan (KSH), 3 bernilai cukup sesuai harapan (CSH), 4 bernilai sesuai harapan (SH), dan 5 bernilai sangat sesuai harapan (SSH). Servqual dapat menghasilkan nilai kesenjangan (gap) antara kenyataan dan harapan melalui rumus berikut (Parasuraman, 1988):

Gap Score = Skor kenyataan- Skor harapan (1)

Tabel 1. Hasil Pengukuran Gap Score Metode Servqual

\begin{tabular}{|c|c|c|c|c|c|}
\hline No & & Atribut Pelayanan & $\begin{array}{c}\text { Skor } \\
\text { Kenyataan }\end{array}$ & $\begin{array}{c}\text { Skor } \\
\text { Harapan }\end{array}$ & $\begin{array}{l}\text { Gap } \\
\text { Score }\end{array}$ \\
\hline 1 & \multirow{8}{*}{ 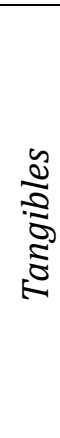 } & Lokasi Strategis & 4.45 & 4.65 & -0.20 \\
\hline 2 & & Kenyamanan Ruang Tunggu & 3.90 & 4.38 & -0.48 \\
\hline 3 & & Penampilan Petugas & 3.79 & 4.32 & -0.53 \\
\hline 4 & & Kelengkapan dan Kebersihan Alat Medis & 4.24 & 4.43 & -0.19 \\
\hline 5 & & Ketersediaan Dokter dan Dokter Gigi & 4.45 & 4.62 & -0.17 \\
\hline 6 & & Ketersediaan Perawat dan Bidan & 4.48 & 4.64 & -0.16 \\
\hline 7 & & Fasilitas Penunjang Memadai & 4.27 & 4.59 & -0.32 \\
\hline 8 & & Ketersediaan Penunjang Medis dan Apotek & 3.89 & 4.58 & -0.69 \\
\hline 9 & \multirow{4}{*}{ 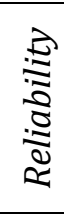 } & Prosedur Penerimaan Cepat dan Tepat & 3.92 & 4.51 & -0.59 \\
\hline 10 & & Pelayanan sesuai SOP & 4.01 & 4.30 & -0.29 \\
\hline 11 & & Jadwal yang Tepat & 3.68 & 4.74 & -1.06 \\
\hline 12 & & Prosedur Pelayanan tidak berbelit & 3.95 & 4.42 & -0.47 \\
\hline 13 & \multirow{4}{*}{ 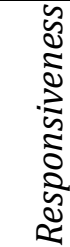 } & Kecepatan Pelayanan Medis & 4.34 & 4.57 & -0.23 \\
\hline 14 & & Ketepatan Pelayanan Medis & 4.36 & 4.62 & -0.26 \\
\hline 15 & & Informasi dari Petugas Jelas dan Dapat dipahami & 4.31 & 4.63 & -0.32 \\
\hline 16 & & $\begin{array}{l}\text { Kesigapan Petugas Menanggapi Keluhan atau } \\
\text { pertanyaan }\end{array}$ & 4.45 & 4.59 & -0.14 \\
\hline 17 & \multirow{5}{*}{ 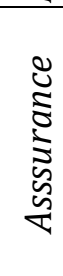 } & Ketepatan Dokter Mendiagnosis & 4.56 & 4.68 & -0.12 \\
\hline 18 & & Ketepatan Terapi & 3.85 & 4.35 & -0.50 \\
\hline 19 & & Ketelitian Petugas dalam Bekerja & 4.17 & 4.47 & -0.30 \\
\hline 20 & & Pelayanan Sopan dan Ramah & 3.88 & 4.81 & -0.93 \\
\hline 21 & & Penjelasan Medis Jelas dan Meyakinkan & 3.95 & 4.40 & -0.45 \\
\hline 22 & \multirow{4}{*}{ 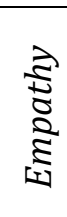 } & Melayani tanpa memandang Status & 4.41 & 4.54 & -0.13 \\
\hline 23 & & Kemudahan Memberikan Kritik dan Saran & 3.70 & 4.27 & -0.57 \\
\hline 24 & & Respon Petugas Baik terhadap Kritik dan Saran & 4.17 & 4.51 & -0.34 \\
\hline 25 & & Kemudahan Memperoleh Informasi Kesehatan & 4.00 & 4.42 & -0.42 \\
\hline
\end{tabular}

Gap score menunjukkan kesenjangan antara kenyataan dan harapan (Parasuraman, 1988). Hal ini menunjukkan adanya masalah ketiaksesuaian antara harapan pelanggan dan kenyataan yang dirasakannya. Berdasarkan Parasuraman (1988) Gap Score bernilai positif (+) menunjukkan bahwa kenyataan dapat memenuhi harapan pelanggan, sedangkan nilai negatif $(-$ ) menunjukkan bahwa belum terpenuhi. Semakin besar gap maka kenyataan semakin jauh dari harapan dan begitu sebaliknya (Zeithaml, 2003). Berdasarkan pada Tabel 4.2 didapatkan bahwa 
nilai gap score terbesar terletak pada atribut ketepatan jadwal pelayanan $(-1.06)$, pelayanan sopan dan ramah (-0.93), ketersediaan penunjang medis dan apotik (-69), prosedur penerimaan pasien yang cepat dan tepat (-0.59), dan Kemudahan Memberikan Kritik dan Saran sebesar ($0.57)$.

\section{Hasil Analisis Importance Performance Analysis (IPA)}

Matriks Importance Performance Analysis yang merupakan plot data dari nilai indeks kinerja tingkat kepentingan dan kepuasan menunjukkan sebaran setiap variabel pada diagram kartesius yang dimana setiap kuadran nya memiliki arti yang berbeda-beda. Variabel-variabel yang masuk dalam kuadran ini harus dipertahankan. Importance Performance Analysis Matrix dapat dilihat pada gambar dibawah ini.

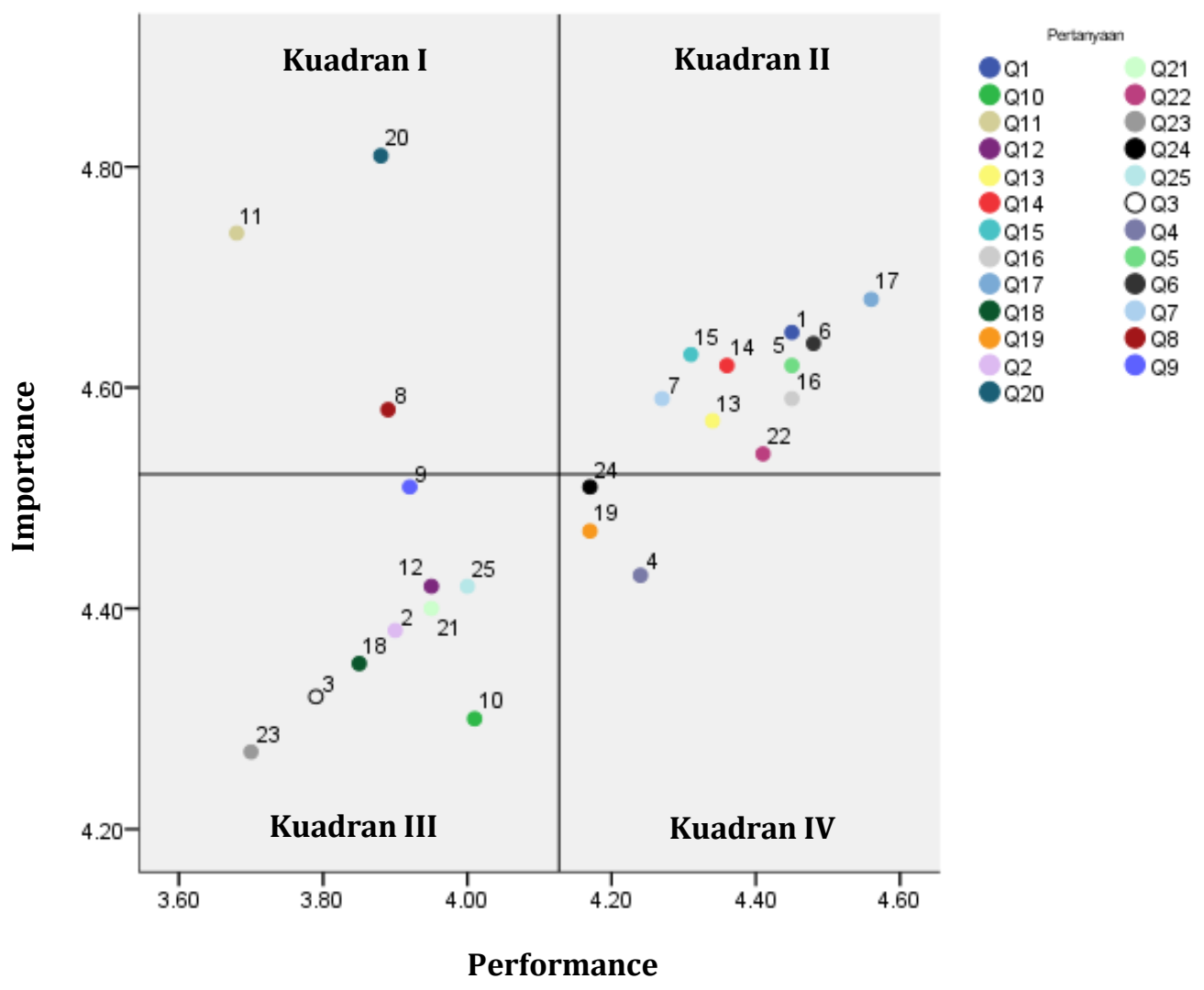

Gambar 2.Hasil Matriks Importance Performance Analysis

Letak kuadran tersebutmenggambarkan keadaan yang berbeda. Pemetaan berdasarkan tingkat kepentingan dan tingkat kinerja ini, memungkinkan pihak dari rumah sakit untuk melakukan perbaikan pada atribut yang dianggap penting oleh pasien dalam jangka waktu relatif dekat. Kuadran I sebagai prioritas utama menunjukan dimensi yang dianggap mempengaruhi kepuasan pelanggan,termasuk dimensi pelayanan yang dianggap sangat penting, namun manajemen belum melaksanakannya sesuai dengan keinginan pelanggan sehingga mengecewakan atau tidak puas. Atribut yang masuk dalam kuadran I dari dimensi tangibles berupa atribut ketersediaan penunjang medis dan apotik, dari dimensi reliability adalah atribut jadwal yang tepat, dan dimensi assuranceberupa atribut pelayanan sopan dan ramah. Kuadran inilah yang harus diprioritaskan untuk diperbaiki.

Kuadran II memuat atribut-atribut dianggap penting oleh konsumen dan atribut-atribut tersebut telah sesuai dengan yang dirasakan konsumen. Atribut yang masuk pada kuadran II dari dimensi tangibles antara lain atribut lokasi strategis, atribut ketersediaan perawat dan bidan dan atribut fasiltas penunjang memadai. Kuadran II dengan dimensi responsiveness berupa atribut kecepatan pelayanan medis, atribut ketepatanpelayanan medis, atribut informasi dari petugas jelas dan dapat dipahami, dan atribut kesigapan petugas menanggapi keluhan atau 
pertanyaan. Kuadran II dengan dimensi assurance berupaatribut ketepatan dokter mendiagnosis dan dimensi empathy berupa atribut melayani tanpa memandang status. Atributatribut yang termasuk dalam kuadran ini harus tetap dipertahankan, karena semua atribut ini menjadikan atribut tersebut unggul di mata konsumen.

Kuadran III merupakan kuadran berkualitas rendah yang memuat atribut-atribut yang dianggap kurang penting oleh konsumen dan pada kenyatannya kinerjanya tidak terlalu istimewa. Atribut yang masuk kuadran III dengan dimensi tangibles adalah atribut kenyamanan ruang tunggu danatribut penampilan petugas. Kuadran III dengan dimensi reliability berupaatribut prosedur penerimaan cepat dan tepat, atribut pelayanan sesuai SOP,danatribut prosedur pelayanan tidak berbelit. Kuadran III dengan dimensi assurance berupa atribut ketepatan terapi dan atribut penjelasan medis jelas dan meyakinkan. Kuadran III dengan dimensi empathy berupaatribut kemudahan memberikan kritik dan saran dan atribut kemudahan memperoleh informasi kesehatan. Peningkatan atribut-atribut yang termasuk kuadran ini dapat dipertimbangkan kembali karena pengaruhnya terhadap manfaat yang dirasakan oleh konsumen kecil.

Kuadran IV memuat atribut-atribut yang dianggap tidak penting oleh konsumen dan dirasakan terlalu berlebihan. Atribut yang masuk dalam kuadran IV pada dimensi tangibles yaitu atribut kelengkapan dan kebersihan alat medis, dimensi assurance berupa atribut ketelitian petugas dalam bekerja, dan dimensi empathy berupa atribut respon petugas baik terhadap kritik dan saran. Dalam hal ini mungkin pihak perusahaan perlu mengurangi tingkat kinerja untuk atribut-atribut yang termasuk dalam kuadran ini.

\section{Pembahasan Hasil Penelitian}

Pelayanan kesehatan yang diberikan oleh petugas kesehatan di Klinik Pratama AP masih belum mampu memenuhi harapan pasien berdasarkan penelitian ini. Evaluasi atribut-atribut yang kurang memenuhi kebutuhan pelanggan ini penting dilakukan oleh pihak manajemen karena pasien sebagai konsumen menjadi pihak penentu yang dapat menilai kualitas layanan sebuah klinik dan sudut pandang pasien menjadi kunci penting evaluasi peningkatan mutu pelayanan (Jabroski, 1992). Penelitian ini menunjukkan bahwa rata-rata pasien sebagai konsumen jasa pelayanan Klinik Pratama AP menyatakan ketidaksesuaian antara apa yang diharapkan dan kenyataan pelayanan yang diterimanya. Sebesar -0,39 rata-rata nilai gapscore Servqual mengindikasikan bahwa secara keseluruhan atribut pelayanan pada klinik ini kurang memenuhi harapan pasien. Nilai gap score terbesar terletak pada atribut ketepatan jadwal pelayanan (-1.06), pelayanan sopan dan ramah $(-0.93)$, ketersediaan penunjang medis dan apotik (-0.69), prosedur penerimaan pasien yang cepat dan tepat $(-0.59)$, dan Kemudahan Memberikan Kritik dan Saran sebesar (-0.57). Beberapa atribut ini menjadi masukan bagi Klinik Pratama AP untuk mempertimbangkan atribut-atribut tersebut untuk dianalisis lebih dalam berdasarkan tingkat kepentingannya.

Analisis lanjutan berupa Importance Perforamance Analysis (IPA) mendistribusikan atribut-atribut kedalam 4 kuadran yang berbeda. Kuadran I menjadi fokus utama perbaikan yang perlu dilakukan oleh pihak manajemen klinik karena kuadran ini menunjukan dimensi yang dianggap paling mempengaruhi kepuasan pelanggan, namun manajemen belum melaksanakannya sesuai dengan keinginan pelanggan sehingga mengecewakan atau tidak puas. Analisis lanjutan IPA menunjukkan terdapat tiga atribut yang termasuk dalam kuadran I, antara lain atribut tepat waktu pelayanan, atribut keramahan dan kesopanan, dan atribut ketersediaan fasilitas penunjang dan apotek. Pihak manajemen Klinik pratama APseharusnya memperhatikan beberapa pertimbangan ini dan meningkatkan lagi pelayanan yang berhubungan dengan ketiga atribut tersebut karena akan berdampak besar bai kepuasan pelanggan dengan cara memperkecil gap (selisih) antara harapan dengan kenyataanyang diterima oleh pelanggan.

Ketepatan waktu pelayanan petugas kesehatan sangat mempengaruhi kepuasan pasien. Ketepatan waktu pelayanan di klinik AP pada kenyataannya memang kurang diperhatikan, kehadiran dokter seringkali terlambat tidak sesuai dengan jadwal yang ditentukan. Kondisi seperti ini membuat pasien yang dating tepat waktu harus menambah waktu tunggu pelayanan 
dan membuat antrian panjang pasien yang akan berobat. Hal ini sejalan dengan hasil penelitian yang dilakukan oleh David, et al (2014), Rustam Effendy(2013), dan Retnaningsih (2013) yang menyatakan bahwa terdapat hubungan yang bermakna antara tingkat kepuasan pasien dengan ketepatan waktu kedatangan dokter untuk menangani pasien di unit rawat jalan. Ketepatan waktu kedatangan dokter dalam melayani pasien akan semakin meningkatkan kepuasan pasien dan apabila dokter datang tidak tepat waktu untuk melayani pasien di unit rawat jalan, maka hal ini akan semakin menurunkan kepuasan pasien.Berdasarkan penelitian lainnya ketepatan waktu juga berhubungan dengan kesiapan petugas dalam pelayanan. Petugas yang datang tidak tepat waktu akan menghambat pelayanan karena petugas tidak memiliki jeda waktu yang optimal untuk mempersiapkan diri melayani pasien.

Atribut kesopanan dan keramahan tergolong dalam dimensi assurance.Beberapa responden masih mengatakan belum puas terhadap kinerja petugas kurang sopan, ramah dan tanggap. Keramahan dan kesopanan petugas kesehatan yang dapat menimbulkan rasa percaya pada pasien karena kepuasan pasien biasanya dikaitkan dengan keramahan petugas yang memberikan pelayanan. Kesopanan dan keramahan dalam penelitian ini meliputi sikap santun, respek, atensi, dan keramahan para petugas kesehatan. Menurut Tjiptono (2014), mutu pelayanan kesehatan bagi seorang pasien tidak lepas dari rasa puas terhadap pelayanan kesehatan yang diterima, dimana mutu yang baik dikaitkan dengan kesembuhan dari penyakit, peningkatan derajat kesehatan, lingkungan perawatan yang menyenangkan, dan keramahan petugas. Menurut Jacobis (2013) pelayanan yang baik harus disertai dengan sikap keramahan dan kesopanan kepada pihak yang dilayani. Sikapini merupakan kemampuan untuk memberikan pelayanan kesehatan dengan tepat waktu dan akurat sesuai dengan yang ditawarkan. Untuk meningkatkan kesopanan dan keramahandi bidang pelayanan kesehatan, pihak manajemen perlu membangun budaya kerja bermutu yang diterapkan mulai dari pimpinan pucak sampai ke petugas yang langsung berhubungan dengan pasien. Budaya kerja seperti ini perlu diterapkan membentuk kelompok kerja yang kompak dan mendapat pelatihan secara terus menerus sesuai dengan perkembangan teknologi dan ekspektasi pasien. Berdasarkan riset variabel ini perlu dikembangkan oleh pihak manajemen institusi pelayanan kesehatan dengan melakukan investasi, tidak saja dalam bentuk uang melainkan keteladanan manajemen puncak, perubahan sikap dan kepribadian staf yang positif, dan perbaikan sistem remunerasinya (Muninjaya, 2011).

Setiap pasien pada dasarnya ingin diperlakukan secara baik oleh pihak pengelola rumah sakit. Adanya jaminan bahwa pasien yang datang akan dilayani secara baik oleh pihak pengelola rumah sakit, akan memberikan rasa aman kepada pasien, sehingga kemantapan pribadi pasien akan bertambah. Dengan demikian, kepercayaan mereka terhadap rumah sakit akan bertambah. Hubungan jaminan dengan kepuasan pasien ialah jaminan mempunyai pengaruh positif dan signifikan terhadap kepuasan pasien. Semakin baik persepsi pasien terhadap jaminan maka kepuasan pasien akan semakin tinggi, dan jika persepsi pasien terhadap jaminan buruk maka kepuasan pasien akan semakin rendah. Penelitian mengenai kepuasan pasien di RSUD Jombang oleh Ariyani (2009), juga menemukan bahwa dimensi jaminan yang baik akan meningkatkan kepuasan pasien terhadap pelayanan rumah sakit, sehingga membuat pasien cenderung percaya dan yakin akan setiap pelayanan yang dilakukan oleh rumah sakit.Sejalan dengan penelitian tersebut, Winardi et al. (2014), dalam penelitian yang berjudul Pengaruh Kualitas Pelayanan Terhadap Kepuasan Konsumen Pasien Rawat Inap di SMC Rumah Sakit Telogorejo bahwa dimensi jaminan berhubungan dengan kepuasan pasien sehingga dapat disimpulkan bahwa jaminan yang baik berhubungan dengan meningkatnya kepuasan pasien serta loyalitas pasien. Dalam penelitian mengenai kepuasan pasien di Selangor, Malaysia, oleh Syafriza et al. (2009) juga menemukan bahwa jaminan yang baik akan meningkatkan kepuasan pasien terhadap pelayanan rumah sakit, sehingga membuat pasien cenderung percaya dan yakin akan setiap pelayanan yang dilakukan oleh rumah sakit.Indiraswari dan Damayanti (2012), menemukan juga bahwa jaminan yang baik secara signifikan selain meningkatkan kepuasan pasien akan pelayanan, juga akan mempengaruhi penilaian pasien akan variabel yang lainnya. Sehingga dapat diperoleh melaluipenelitian ini bahwa dimensi Jaminan (assurance) berpengaruh terhadap kepuasan Pelanggan pasien di layanan kesehatan. 
Atribut ketersediaan fasilitas penunjang dan apotek pada klinik AP termasuk dalam dimensi tangibles. Atribut ini dirasakan oleh beberapa responden sangat perlu ditingkatkan. Pernyataan ini berdasarkan beberapa keterbatasan pelayanan yang dirasakan. Keterbatasan pelayanan ini terutama saat akan melakukan pemeriksaan penunjang laboratorium yang masih bekerja sama dengan pihak eksternal. Sehingga banyak pasien harus berkunjung ke labortorium eksternal dan kembali lagi untuk menunjukkan hasil pemeriksaannya. Hal ini dirasakan sangat tidak efisien oleh pasien. Selain itu, beberapa kelengkapan apotek juga perlu ditingkatkan, seperti fasilitas tunggu saat menunggu obat yang masih minimal dan kurang memberikan kemudahan bagi pasien saat dilayani. Harapan lainnya pasien juga membutuhkan fasilitas ruangan pelayanan yang lebih nyaman.

Fasilitas merupakan segala sesuatu yang sengaja disediakan oleh penyedia jasa untuk dipakai serta dinikmati oleh konsumen yang bertujuan memberikan tingkat kepuasan yang maksimal. Fasilitas merupakan segala sesutau yang bersifat peralatan fisik yang disediakan oleh pihak penjual jasa untuk mendukung kenyamanan konsumen (Kotler, 2009). Sedangkan Menurut Bata (2013)fasilitas merupakan penampilan, kemampuan sarana prasarana dan keadaan lingkungan sekitarnya dalam menunjukkan eksistensinya kepada eksternal yang meliputi fasilitas fisik (gedung) perlengkapan dan peralatan. Yang termasuk fasilitas dapat berupa alat, benda-benda, perlengkapan, uang, ruang tempat kerja. Menurut Tjiptono (2006) desain dan tata letak fasilitas jasa erat kaitannya dengan pembentukan presepsi pelanggan. Sejumlah tipe jasa, presepsi yang terbentuk dari interaksi antara pelanggan dengan fasilitas berpengaruh terhadap kualitas jasa tersebut di mata pelanggan.Fasilitas dapat juga diartikan sebagai sarana dan prasarana yang tersedia di lingkungan maupun di dalam kantor perusahaan, dimaksudkan untuk memberikan pelayanan maksimal agar konsumen atau pelanggan merasakan nyaman dan puas.

Perusahaan yang memberikan suasana menyenangkan dengan desain fasilitas yang menarik akan mempengaruhi konsumen dalam melakukan pembelian. Artinya bahwa salah satu faktor kepuasan konsumen dipengaruhi oleh fasilitas yang diberikan oleh penjual yang dimanfaatkan oleh konsumen sehingga mempermudah konsumen dalam proses pembelian. Apabila konsumen merasa nyaman dan mudah mendapatkan produk atau jasa yang ditawarkan oleh penjual, maka konsumen akan merasa puas. Menurut Ari (2013) pemberian fasilitas yang memadai akan membantu meningkatkan empati konsumen terhadap setiap kondisi yang tercipta pada saat konsumen melakukan pembelian. Sehingga secara psikologis mereka akan memberikan suatu pernyataan bahwa mereka puas dalam melakukan pembeliannya.Hal ini sejalan dengan penelitian lainnya yaitu penelitian Yunus (2014) yang menyatakan fasilitas menjadi tolak ukur bagi pelanggan untuk mengukur tingkat kualitas pelayanan dan memiliki efek yang sangat tinggi bagi tingkat kepuasan pelanggan. Hal ini sejalan dengan penelitian Steffi (2013) yang menemukan bahwa fasilitas dan kualitas pelayanan secara simultan dan parsial berpengaruh signifikan terhadap kepuasan pelanggan rumah sakit.Kualitas pelayanan yang baik tentunya menciptakan kepuasan pengguna layanan.

Yuda (2012) dengan judul analisis pengaruh kualitas pelayanan, harga dan fasilitas terhadap kepuasan pasien rawat jalan di Rumah SakitKariadi Semarang. Hasil analisis menunjukkan bahwa antara variabel kualitas pelayanan, harga dan fasilitas mempunyai pengaruh yang positif signifikanterhadap variabel kepuasan konsumen, baik secara individu maupunbersama. Besarnya Adjusted $R$ Square adalah 0,836. Hal ini berarti bahwa83,6\% variasi kepuasan konsumen dapat dijelaskan oleh ketiga variable bebas kualitas pelayanan, harga, dan fasilitas.fasilitas merupakan salah satu sumber daya fisik yang harus ada sebelum suatu jasa dapat ditawarkan kepada konsumen. Dalam usaha yang bergerak dibidang jasa, fasilitas yang ada yaitu kondisi fasilitas, kelengkapan desain interior dan eksterior serta kebersihan fasilitas dipertimbangkan terutama yang berkaitan erat dengan apa yang dirasakan atau didapat konsumen secara langsung.Secara umum menunjukkan bahwa kualitas pelayanan dan fasilitas merupakan faktor yang penting agar diperoleh tingkat kepuasan pelanggan yang tinggi. Dengan adanya kualitas pelayanan yang baik dan fasilitas yang baik pula, maka minat pelanggan untuk 
menggunakan kembali jasa yang pernah digunakannya akan tumbuh, begitu juga dengan sebaliknya.

Fasilitas yang memadai perlu dipenuhi oleh penyedia jasa untuk menumbuhkan loyalitas. Penyedia jasa harus terlebih dahulu memberikan kepuasan kepada pelanggannya untuk mencapai loyalitas pelanggan. Kepuasan tersebut dapat dicapai dengan memberikan fasilitas yang baik juga memadahi dan kualitas pelayanan yang optimal. loyalitas bisa terbentuk apabila pelanggan merasa puas dengan merasakan fasilitas yang baik dan memadahi serta kepuasan yang diterima melalui tingkat pelayanan yang diterima (Lutfi, 2013). Berdasarkan penelitian Lutfi (2013), Fasilitas yang mampu memenuhi kebutuhan pelanggan akan berdampak pada munculnya kepuasan pelanggan dan mendorong munculnya loyalitas pelanggan. Hal ini dinilai akan berdampak baik bagi penyedia jasa.Menurut Engel, et al dalam Alma (2007) kepuasan pelanggan merupakan evaluasi purnabeli dimana alternatif yang dipilih sekurang-kurangnya sama atau melampaui harapan pelanggan. Pelanggan adalah seseorang yang merasa kontinyu dan berulang kali datang ke suatu tempat yang sama untuk memuaskan keinginanya dengan memiliki suatu produk atau mendapatkan suatu jasa dan membayar produk atau jasa tersebut.

Menurut Fredeick F Reicheld dalam Rangkuti(2008), jika konsumen mempunyai keinginan penuh membeli suatu layanan tertentu lagi, pada saat konsumen membutuhkan layanan tersebut, itulah yang disebut loyalitas. Konsumen yang puas terhadap barang atau jasa yang dikonsumsinya akan mempunyai kecenderungan untuk membeli ulang dari produsen yang sama (Widyaswati, 2010). Maka dari itu dengan adanya kepuasan pelanggan, dapat menimbulkan loyalitas konsumen. Loyalitas dapat diartikan sebagai kesetiaaan. Kesetiaan konsumen ditunjukan dengan pembelian ulang barang atau jasa yang diminati secara terus menerus. Menurut Fredeick F Reicheld dalam Rangkuti (2008), jika konsumen mempunyai keinginan penuh membeli suatu layanan tertentu lagi, pada saat konsumen membutuhkan layanan tersebut, itulah yang disebut loyalitas. Sehingga fasilitas merupakan segala sesuatu yang sengaja diberikan oleh penyedia jasa untuk dipakai serta dinikmati oleh konsumen yang bertujuan membuat konsumen loyal.

\section{KESIMPULAN}

Penelitian ini mengidentifikasi 25 atribut pelayanan yang terbagi ke dalam 5 dimensi pelayanan. Pada dimensi Tangibles diperoleh 8 atribut antara lain berupa lokasi yang strategis, kenyamanan ruang tungg, penampilan petugas, kelengkapan dan kebersihan alat medis, ketersediaan dokter dan dokter gigi, ketersediaan perawat dan bidan, fasilitas penunjang memadai dan ketersediaan penunjang medis dan apotek. Pada dimensi reliability diperoleh sejumlah empat atribut pelayanan antara lain prosedir penerimaan pasien yang cepat dan tepat, pelayanan sesuai SOP, jadwal yang tepat dan prosedir pelayanan tidak berbelit-belit. Pada dimensi responsiveness terdiri dari empat atribut antara lain kecepatan pelayanan medis, ketepatan pelayanan medis, infromasi dari petugas jelas dan dapat dipahami, kesigapan petugas menanggapi keluhan atau pertanyaan. Dimensi assurance disusun oleh lima atribut pelayanan antara lain ketepatan dokter mendiagnosis, ketepatan terapi, ketelitian petugas dalam bekerja, pelayanan sopan dan ramah, dan penjelasan medis jelas dan meyakinkan. Pada dimensi terkahir yaitu empathy terdapat empat atribut antara lain melayani tanpa memandang status, kemudahan memberikan kritik dan saran, respon petugas baik terhadap kritik dan saran dan kemudahan memperoleh informasi kesehatan.

Penelitian ini menemukan bahwa kualitas pelayanan di Klinik Prtama AP belum mampu memenuhi harapan pasien anggota BPJS. Peningkatan jumlah komplain yang menjadi latar belakang penelitian ini disebabkan oleh adanya ketidakpuasan pasien terhadap pelayanan yang diberikan. Ketidakmampuan pemenuhan kebutuhan pasien ini menjadi sebuah ketidakpuasan terhadap suatu pelayanan yang ditunjukkan oleh gap scoreyang bernilai negatif pada semua atribut pelayanan dengan rata-rata sebesar -0,39 berdasarkan analisis Servqual. Analisis servqual menghasilkan 5 atribut dengan gapscore yang tertinggi yaitu atribut ketepatan jadwal pelayanan $(-1.06)$, pelayanan sopan dan ramah $(-0.93)$, ketersediaan penunjang medis dan 
apotik (-0.69), prosedur penerimaan pasien yang cepat dan tepat (-0.59), dan Kemudahan Memberikan Kritik dan Saran sebesar (-0.57).

Hasil analisis menggunakan Importance Performance Analysis (IPA) mendistribusikan 25 atribut pelayanan kedalam 4 kuadran. Kuadran I merupakan kuadran prioritas karena pada kuadran ini berisikan atribut yang paling berpengaruh pada kepuasan pasien dan pasien merasa atribut pada kuadran ini paling diharapkan namun belum dimaksimalkan oleh pihak manajemen. Kuadran I yang menjadi prioritas pada penelitian ini berisikan atribut ketepatan jadwal pelayanan, pelayanan sopan dan ramah, dan ketersediaan penunjang medis dan apotik. Sehingga berdasarkan kedua analisis tersebut dapat diperoleh tiga atribut prioritas yang perlu dimaksimalkan oleh pihak manajemen yang ditujukan untuk meningkatkan kualitas layanan yang belum mampu memennuhi harapan pasien BPJS sebagai pelanggan Klinik Pratama AP. Atribut prioritas tersebut merupakan atribut dengan nilai gapscore terbesar Servqual dan masuk kedalam kuadran I analisis Importance Performance Analysis yang bermakna atribut tersebut merupakan atribut yang saat ini belum dimaksimalkan oleh manajemen namun memiliki potensi untuk meningkatkan kualitas layanan dan sesuai dengan harapan pelanggan Klinik Pratama AP.

Implikasi manajemen pada penelitian ini adalah hasil penelitian ini mampu menganalisis kualitas pelayanan di Klinik Pratama AP dan menjadikan hasil prioritas atribut sebagai pertimbangan bagi klinik untuk meningkatkan kualitas pelayanannya berdasarkan pada kebutuhan pelanggan agar permasalahan yang terjadi dapat terselesaikan dengan melalui tahapan yang efektif dan efisien. Menghilangkan kesenjangan tersebut dengan memberikan kesempatan kepada para pelanggan untuk menyampaikan ketidakpuasan mereka kepada manajemen dan menjadikannya sebagai bahan evaluasi di masa yang akan dating untuk kualitas pelayanan yang lebih baik. Implikasi akademik penelitian ini adalah penggunaan analisis Servqual dan Importance Performance Analysis (IPA)dapat diterapkan pada di bidang pelayanan kesehatan pada tingkat fasilitas kesehatan tingkat pertama (FKTP), analisis ini dapat menjadi masukan bagi manajemen dalam perspektif pelanggan, melakukan penelitian lanjutan dengan penambahan jumlah sampel penelitian dan integrasi hasil analisis kualitas pelayanan dengan sampel internal manajemen akan menguatkan hasil analisis berdasarkan perspektif internal maupun eksternal manajemen sehingga dapat menghasilkan data yang lebih komprehensif .

Keterbatasan penelitian ini tidak melakukan intervensi pada manajemen sehingga tidak dapat memberikan hasil analisis dampak setelah diterapkannya hasil prioritas analisis Servqual dan Importance Performance Analysis (IPA). Integrasi metode Servqual dan Importance Performance Analysis (IPA) merupakan metode sederhana untuk diterapkan namun tidak cukup komprehensif membahas setiap korelasi antara kebutuhan pelanggan dan respon manajemen sehingga dibutuhkan analysis lanjutan seperti analisis Quality Function Deployment (QFD) di masa yang akan datang agar hasil analisis kualitas pelayanan dapat didasarkan juga pada pihak manajemen.

\section{DAFTAR PUSTAKA}

Alma, Buchari. 2007. Bunga Rampai Strategi Manajemen Bisnis Berbasis Hasil Penelitian. Edisi Ketiga, Cetakan Kesatu. Alfabeta: Bandung.

Ariani, D. Wahyu. 2009. Manajemen Operasi Jasa. Yogyakarta : Graha Ilmu

Arief, B. M. 2015. Sistem Jaminan Sosial Nasional Program Jaminan Kesehatan BPJS Kesehatan. Grup Pemasaran BPJS Kesehatan.

Azwar, S. 2000. Sikap Manusia, Teori dan Pengukuranya. Jogjakarta: Pustaka Pelajar Jogja Offset.

Bata, Y. W., Arifin, H. Muh. A., Darmawansyah. 2013. Hubungan Kualitas Pelayanan Kesehatan Dengan Kepuasan Pasien Pengguna Askes Sosial Pada Pelayanan Rawat Inap di RSUD Lakipadada Kabupaten Tana Toraja Tahun 2013. Hal. 1-12. 
Budiman, S., \& Herlina, N. 2010. Hubungan Status Demografi Dengan Kepuasan Masyarakat Tentang Pelayanan Jamkesmas Di Wilayah Puskesmas Tanjungsari Kabupaten Bogor Tahun 2010. Jurnal Kesehatan Kartika, 27, 1989-2009.

David. 2014. The Impact of Motivation on Employee Performance in the Manufacturing Industry in Ghana. Global Journal of Management Studies and Researches, 1(5), Pages: 291-310

Gunarsa, Singgih. D., Yulia Singgih D. Gunarsa. 2008. Psikologi praktis: anak, remaja, dan keluarga. Jakarta: Gunung Mulia.

Indra, Ari P dan Hari S. 2013. Pengaruh Fasilitas dan Kualitas Pelayanan Terhadap Loyalitas, Melalui Kepuasan Konsumen Sebagai Variabel Intervening pada Star Clean Car Wash Semarang.Diponegoro Journal Of Social And Politic, Hal. 1-12

Iswandari, Krisnawati. 2011. Desain Dan Rencana Mutu Pelayanan Di Unit Rawat Jalan Rumah Sakit Qadr Tangerang Tahun 2011-2016 Dengan Metode Servqual - QFD (Quality Function Deployment). Fakultas Kesehatan Masyarakat. Universitas Indonesia. Jakarta.

Jacobis, R. 2013. Faktor-Faktor Kualitas Pelayanan Pengaruhnya Terhadap Kepuasan Pasien Rawat Inap Peserta Jamkesmas Di BLU RSUP Prof. Dr. RD Kandou Manado. Jurnal EMBA: Jurnal Riset Ekonomi, Manajemen, Bisnis dan Akuntansi, 1(4).

Kemenkes RI. Rencana strategis Kementerian Kesehatan 2010-2014. Jakarta: Kemenkes RI.

Kotler, Philip. 2009. Manajemen Pemasaran, Jilid 2, Edisi 13. Alih Bahasa Benyamin Molan. Jakarta: Prehallindo.

Kurniawan. 2012. Gap Analisis Kualitas Pelayanan (Servqual) Di Klinik Ims (Infeksi Menular Seks) Puskesmas Ii Baturaden Kabupaten Banyumas. Skripsi. Banyumas: Universitas Jenderal Soedirman.

Magdalena, Marito, Sugiharto, dan Rosnani G. 2013. Peningkatan Kualitas Pelayanan Dengan Menggunakan Metode Quality Function Deployment (QFD) Di Rumah Sakit XYZ. E-Jurnal Teknik Industri FT USU Vol 3. Pp 31-37

Moenir, A.S. 2010. Manajemen Pelayanan Umum Di Indonesia. Jakarta: Bumi Aksara.

Muninjaya, Gde A. A.(2011). Manajemen Mutu Pelayanan Kesehatan. Jakarta: EGC.

Nuresa, Esa. 2010.Kualitas Pelayanan Kesehatan Bagi Pengguna Askeskin di Puskesmas I Purwokerto Timur. Skripsi. Banyumas: Universitas Jendral Soedirman

Parasuraman, Zeithmal, dan A. Berry. 1988. Servqual: Multiple-item Scale for Measuring Consumer Perceptions of Service Quality, Journal of Retailing.

Parasuraman, Zeithmal, dan A. Berry. 1985. A Conceptual Model of Service Quality and Its Implication for Future Research, Journal of Marketing, Vol. 49.

Pratiwi, Dinar Ika. 2010. Analisis pengaruh harapan pelanggan, kualitas produk, kepuasan pelanggan terhadap loyalitas pelanggan internet flash unlimited di Semarang. Semarang: Universitas Diponegoro

Rangkuti, Freddy. 2008. The Power of Brands, Teknik Mengelola Brand Equity dan Strategi Pengembangan Merk. Jakarta: PT Gramedia Pustaka Utama.

Retnaningsih, E, 2013, Akses Layanan Kesehatan,Raja Grafindo Persada, Jakarta

Retnaningsih, E. 2013. Akses Layanan Kesehatan. Jakarta: Raja Grafindo Persada

Rustam, Effendy. Marketing Manajemen. Malang: Penerbit Institut Ekonomi dan Manajemen, 2001

Sartinah. 2008. Kualitas Pelayanan Kesehatan (Studi tentang Pengaruh Kemampuan dan Disiplin Kerja Pegawai terhadap Kualitas Pelayanan Kesehatan di Puskesmas II Baturaden Kecamatan Baturaden Kabupaten Banyumas). Skripsi. Banyumas: Universitas Jenderal Soedirman.

Steffi Mongkaren. 2013. Pengaruh Fasilitas dan Kualitas Pelayanan Terhadap Kepuasan Pelanggan Rumah Sakit Advent Manado. Jurnal. UNY.

Sugiyono. 2012. Metode Penelitian Kuantitatif, Kualitatid dan R\&D. Bandung: Alfabeta.

Supartiningsih. 2017. Kualitas Pelayanan dan Kepuasan Pasien Rumah Sakit: Kasus Pada Pasien Rawat Jalan Jurnal Medicoeticolegal dan Manajemen Rumah Sakit, 6 (1): 9-15, Januari 
Syafriza. D., R. Hayati dan I. K. Indiarti. 2009. The correlation between children nutritional status with calcification stages of mandibulary premolar tooth germ. I n: Burket LW, Greenberg MS, ed. KPPIKG 2009 15th Scientific Meeting and Refresher Course in Dentistry Faculty of Dentistry

Tjiptono, F. 2014. Pemasaran Jasa, Prinsip, Penerapan, dan Penelitian. Jogyakarta: Andi Publisher

Tjiptono, Fandy. 2006. Manajemen Jasa. Yogyakarta: Andi.

Tjiptono. 2003 Total Quality Management.n Revisi, E., ed., Yogyakarta: Percetakan Andi.

Trisnawati, Komang. 2015. Analisis kepuasan pasien rawat jalan Pns Pada Masa Pelaksanaan Askes Dan Jkn Di Rsup Dr.sardjito Yogyakarta.Tesis, Universitas Gajah Mada, Yogyakarta, Indonesia.

Umar. 2005. Metodologi Penelitian, Aplikasi dalam Pemasaran, Jakarta: PT. Gramedia Pustaka Utama.

Wahyuni, Rahmi, dan Nurwahyuni, Atik. 2014. Gambaran Kepuasan Peserta BPJS Kesehatan Terhadap Pelayanan Kesehatan Rawat Jalan di Rumah Sakit Palang Merah Indonesia. Fakultas Kesehatan Masyarakat. Universitas Indonesia. Bogor

Widyaswati, Rahmatya. 2010. Analisis Faktor - Faktor yang Mempengaruhi Kepuasan Sehingga Tercipta Word of Mouth yang Positif Pada Pelanggan Speedy di Semarang. Tesis S2 Program Megister Manajemen. Universitas Diponegoro. Semarang.

Winardi, H., W. Hidayat, dan A. Wijayanto. 2014. Pengaruh Kualitas Pelayanan Terhadap Kepuasan Konsumen Pasien Rawat Inap Di Smc Rumah Sakit Telogorejo. Fakultas Ilmu Sosial dan Ilmu Politik, Universitas Diponegoro

Yuda Supriyanto. 2012. Analisis Pengaruh Kualitas Pelayanan, Harga, dan Fasilitas Terhadap Kepuasan Pasien Rawat Jalan di Rumah Sakit Kariadi Semarang. Jurnal Manajemen. Universitas Diponegoro.

Yunus Dan Budiyanto. 2014. Pengaruh Kualitas Pelayanan Dan Fasilitas Terhadap Kepuasan Pelanggan. Jurnal Ilmu \& Riset Manajemen Vol 3, No 12 